\title{
Obturator bypass in the treatment of prosthetic graft infection: Classic but still effective
}

\author{
Enfekte prostetik greft tedavisinde obturator baypas: Eski fakat hala etkili
}

\author{
Gökalp Altun ${ }^{1}{ }^{1}$, Zerrin Pulathan ${ }^{1}{ }^{1}$, Doğuş Hemsinli (D) ${ }^{2}$ \\ Institution where the research was done: \\ Karadeniz Technical University, Trabzon, Turkey
}

Author Affiliations:

'Department of Cardiovascular Surgery, Medicine Faculty of Karadeniz Technical University, Trabzon, Turkey ${ }^{2}$ Department of Cardiovascular Surgery, Medicine Faculty of Recep Tayyip Erdoğan University, Rize, Turkey

\begin{abstract}
Aortic graft infection is associated with high mortality and morbidity rates. In this article we report a 60 -year-old man who developed bilateral groin wound infection and progressively worsening lower extremity ischemia one year after he underwent aortobifemoral bypass. The infected graft was resected and bilateral obturator bypass was performed. The obturator bypass, an extra-anatomical bypass closest to anatomical position with high patency rates, continues to be favored in revascularization of the lower extremity when the inguinal region should be avoided. Likewise, the obturator bypass is an effective surgical approach against recurrent infections.
\end{abstract}

Keywords: Bilateral; graft infection; obturator bypass; synchronous.

Prosthetic graft infection is one of the major complications of vascular surgery. The incidence of graft infection of the inguinal region is between $1.3 \%$ and $6 \%$. Postoperative amputation and mortality rates of $52 \%$ and $58 \%$, respectively, have been reported in association with surgery. ${ }^{[1]}$

Infection localized in the inguinal region can be treated with local methods, such as bacterium-specific antibiotic therapy and folding a muscle flap around the graft, or the interposition of a new prosthesis with the removal of the infected part. If bleeding or extremity ischemia associated with graft thrombosis is present, the therapeutic protocol consists of systemic antibiotic therapy along with removal of the infected graft,

\section{$\ddot{O} Z$}

Aortik greft enfeksiyonu, yüksek mortalite ve morbidite oranlarıyla ilişkilidir. $\mathrm{Bu}$ yazıda aortobifemoral baypas ameliyatı uygulandıktan bir yıl sonra kasık yara yeri enfeksiyonu ve alt ekstremite iskemisi gelişen 60 yaşındaki erkek hasta sunuldu. Enfekte greft çıkarıldı ve hastaya iki taraflı obturator baypas uygulandı. Obturator baypas, yüksek açıklık oranları ve anatomik pozisyona en yakın ekstra-anatomik baypas olmasıyla, inguinal bölgeden kaçınılması gerektiğinde alt ekstremite revaskülarizasyonunda halen tercih edilmektedir. Sonuç olarak, obturator baypas tekrarlayan enfeksiyonlara karş1 etkili cerrahi yaklaşımdır.

Anahtar sözcükler: İki taraflı; greft enfeksiyonu; obturator baypas; eş zamanlı.

debridement of infected tissues and re-establishment of extremity circulation..$^{[2,3]}$ Although infection-resistant synthetic grafts or allografts have been increasingly used in recent years, extra-anatomical revascularization is the most suitable surgical technique for overcoming extremity ischemia when these are not possible. ${ }^{[4]}$ Obturator bypass can be easily used in vascular infections of the inguinal region since they pass through deeper anatomical planes when compared to other extra-anatomical bypasses, and shorter grafts are used..$^{[2,3]}$

We report a case of infected graft excision and bilateral obturator bypass in a patient who developed graft infection and occlusion in both inguinal regions

Received: December 07, 2017 Accepted: April 03, 2018

Correspondence: Gökalp Altun, MD. Karadeniz Teknik Üniversitesi Tip Fakültesi Kalp ve Damar Cerrahisi Anabilim Dall, 61080 Ortahisar, Trabzon, Turkey. Tel: +90 462 - 3775927 e-mail: gokalpaltun@gmail.com 


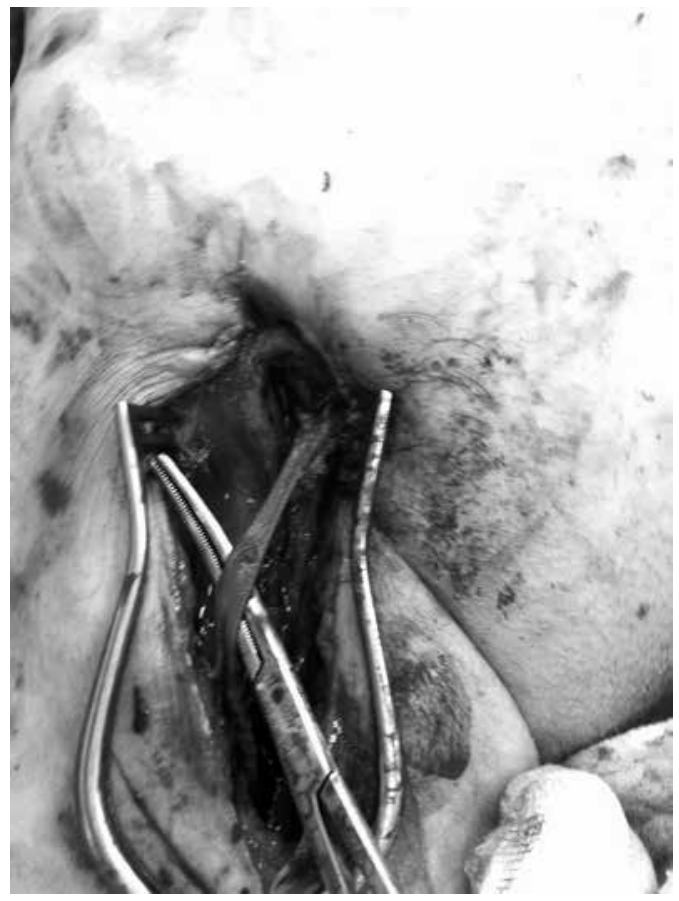

Figure 1. Intraoperative view of the patient's groin after resection of the infected vascular graft. Fistulization was observed in the upper end of the incision.

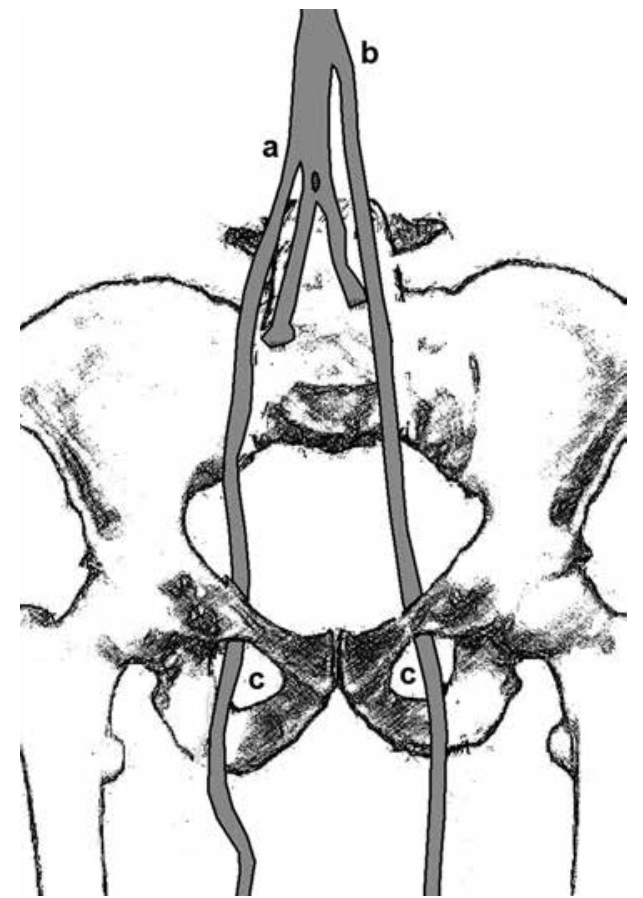

Figure 2. Illustration showing the proximal anastomosis sites in this case and the passage through the obturator canals.

a- proximal anastomosis site of the right-side graft; $b$ - proxima anastomosis site of the left-side graft; c- the passage of grafts through the obturator canal. after he previously underwent aortobifemoral bypass. This is a rare case of obturator bypass performed bilaterally in the same session.

\section{CASE REPORT}

A 60-year-old male patient with diabetes presented to our clinic with bilateral groin wounds, bilateral claudication that began after a walking distance of 15-20 meters, and ischemic ulcer on the right third toe. The patient had undergone aortobifemoral bypass due to Leriche's syndrome one year previously.

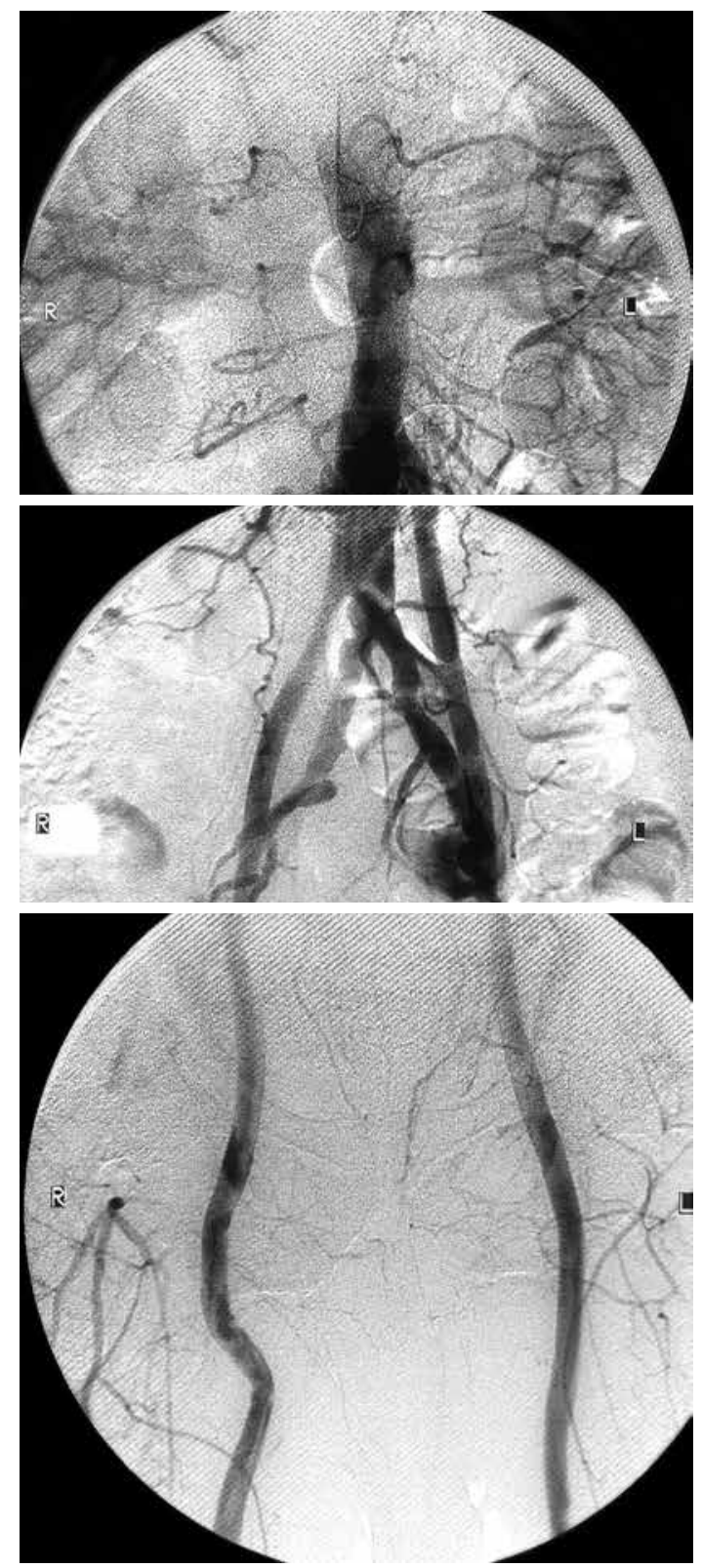

Figure 3. Digital subtraction angiography image at five-year follow-up. The grafts are patent. 
Ankle Brachial Index (ABI) was 0.5 on the right and 0.7 on the left. Angiography revealed total occlusion of the aortobifemoral graft. One week following medical treatment and wound care, prosthetic graft infection was diagnosed and the patient was taken for surgery. The occluded and infected graft was removed with laparotomy and incisions were made in the old wound sides in both groin regions (Figure 1). The aortic proximal anastomosis region was closed with double-layer pledgeted sutures. Two separate proximal anastomoses were performed from the aortic stump with 8-mm silver coated ringed expanded polytetrafluoroethylene (ePTFE) grafts. The distal ends of the grafts were passed through the bilateral obturator foramen (Figure 2). A hybrid graft was composed by adding the saphenous vein graft taken from the thigh to the ePTFE graft. Distal anastomoses were performed to the distal superficial femoral arteries at the outlet of the Hunter's canal on both sides. A sartorius muscle flap was applied to both inguinal regions. The patient's distal pulses were strong, and ABI was 1.0. The patient was discharged with no clinical symptoms on the $16^{\text {th }}$ day. Ischemic and infected ulcers were completely healed in outpatient clinic follow-up, and the patient did not develop any infective complications. The patient had no symptoms other than diabetic neuropathy at the end of five years, and ABI was 0.8 on both sides. Postoperative angiography showed bilateral patent obturator grafts. (Figure 3).

\section{DISCUSSION}

Removal of the infected prosthesis is a common feature of different surgical methods. Following graft removal, either in situ implantation methods or extra-anatomical bypass operations must be performed. ${ }^{[2]}$ Graft removal and primary amputation can also be life-saving in patients with severe hemorrhage, sepsis, or poor general condition. $^{[2-4]}$ Axillofemoral bypass followed by initial removal of the infected graft may be recommended in aortic graft infections. However, due to the length of axillofemoral grafts, they have certain disadvantages, such as a disposition to thrombosis, close proximity to the skin, and vulnerability to external pressure. Today, the obturator bypass is regarded as providing permanent extraanatomical reconstruction and as the extra-anatomical bypass closest to anatomical position. ${ }^{[5,6]}$

Obturator, lateral femoral, lateral transiliac, and gluteopopliteal bypasses are single-stage extraanatomical procedures used in lesions of the femoral region. Obturator bypasses have five-year patency levels of $89 \%$. The technique was first described by Shaw and Baue in 1962. ${ }^{[7]}$ Obturator bypasses are most commonly used in patients with infected false aneurysms and prostheses of the femoral region. Other reported cases include diffuse epidermoid carcinoma and radiation necrosis, extensive soft tissue loss secondary to trauma, presence of intensive scar tissue, and conditions that frequently use the arteries in the femoral region as inflow vessels such as femorodistal bypass. ${ }^{[5,6]}$ Distal anastomosis can be performed to the femoral, popliteal, or profunda arteries outside the infected region. ${ }^{[6]}$

The primary purpose of obturator bypass is to maintain continuity of the new graft away from the area of infection and to protect the graft against bacterial contamination..$^{[2]}$ Muscular flaps must also be used to preserve graft function and to ensure efficient wound healing. ${ }^{[1-4]}$ The surgeon must be experienced and well-acquainted with the anatomy of the region. The most common complication is injury to the obturator artery and nerve that pass through the lateral superior margin of the obturator canal. Injury to the obturator nerve may result in restricted hip adduction and mobility. Other complications include bladder rupture and false aneurysm of the graft itself. Another disadvantage of the obturator bypass is the need for a large surgical site to design the pathway. ${ }^{[5,6]}$

Review of the literature shows that obturator bypass surgery is generally performed unilaterally. Cases of bilateral obturator bypass are scarce..$^{[5]}$ Our case is distinguished from other reports in that the bilateral bypass was performed in the same operation and that proximal anastomoses were performed separately to the aorta to prevent the ascendant spread of potential new infection from one side to the contralateral graft.

In conclusion, the obturator bypass continues to be favored in lower extremity revascularizations when the inguinal region should be avoided, for reasons such as high early and late patency rates and being the extra-anatomical bypass option closest to the anatomical position. Finally, the obturator bypass is the most effective surgical approach against recurrent infection.

\section{Acknowledgments}

The authors thank Okan Ozdemir, Engineer, for his illustration assistance for this study.

\section{Declaration of conflicting interests}

The authors declared no conflicts of interest with respect to the authorship and/or publication of this article.

\section{Funding}

The authors received no financial support for the research and/or authorship of this article. 


\section{REFERENCES}

1. Siracuse JJ, Nandivada P, Giles KA, Hamdan AD, Wyers MC, Chaikof EL, et al. Prosthetic graft infections involving the femoral artery. J Vasc Surg 2013;57:700-5.

2. Engin C, Posacioglu H, Ayik F, Apaydin AZ. Management of vascular infection in the groin. Tex Heart Inst J 2005;32:529-34.

3. Masaki H, Tabuchi A, Yunoki Y, Kuwata N, Tamura T, Honda T, et al. Long-term results of obturator bypass. Ann Vasc Dis 2016;9:80-4.

4. Patel A, Taylor SM, Langan EM 3rd, Snyder BA, Cull DL,
Sullivan TM, et al. Obturator bypass: a classic approach for the treatment of contemporary groin infection. Am Surg 2002;68:653-8.

5. Thompson JK, Strunk RS, Giglia JS. Bilateral obturator bypass for combined aortic and femorofemoral graft infection. J Vasc Surg 2006;44:888.

6. Onoda M, Furutani A, Akiyama N, Morikage N, Yoshimura K, Hamano K. Infected aneurysms of bilateral deep femoral arteries due to Campylobacter fetus subspecies fetus. Ann Vasc Surg 2008;22:476-80.

7. Shaw RS, Baue AE. Management of sepsis complicating arterial reconstructive surgery. Surgery 1963;53:75-86. 